\title{
The House of Memory
}

\author{
Penn Kemp
}

\section{La maison de la mémoire}

L'année dernière, je ne me souvenais pas de mes rêves, je ne me souvenais pas de mes noms, je ne me souvenais de rien. Cela me faisait peur. Faisant du rêve la métonymie de la mémoire, j' essayais chaque matin de rappeller les rêves, d'enécrire tous les fragments, de travailler une image jusqu'à ce qu'elle me rende le récit entier. Je ne cédais pas tandis que ma mémoire ne me ramenait pas de détails. J' essayais toutes sortes de ruses. Finalement, la mémoire a cessé de me résister et nous travaillons bien ensemble maintenant. Beaucoup de rêves dont je me souviens concernent la maison de ma grand-mère. Les maisons dans les rêves fonctionnent comme une conscience archaïque ou archétypale, symbolisant une partie de moimême fixée à une certaine période de ma vie. Elles sont plutôt liées à la situation présente qu' au passé. La maison de l'enfance dans le rêve est fragmentée, dispersée, une pièce par ici, l'autre par là. Le rêve rassemble les trois temps pour que le passé rencontre l'avenir au présent de l'écriture. Ainsi, l'héritage ancestral concentré dans la maison de ma grand-mère se superpose avec des cultures apprises et choisies pour constituer le mélange que je reconnais comme "moi-même." Des juxtapositions bizarres se font dans le rêve et se poursuivent dans les poèmes qui en découlent.

For a while last year, I was not remembering dreams, not remembering names, not remembering. I was frightened. Using the dream as metonymy for the whole of memory, I zeroed in on recalling what I could each morning, waking up, writing fragments down, worrying an image until it led me back into the whole narrative. My will would not let go until my memory surfaced with the goods. I returned to the same sleeping position from which I had awakened, and let my mind sink into that repose. I knew tricks, the subterfuge of setting a specific task to remember and seeming to let it go, waiting until my unconscious came up with the matter. Finally, my memory learned that I was a bulldog, that it was 
simpler to appease me than to resist. So now we work together more easily and I remember several dreams a night.

If I dream of the houses I lived in as a child, it seems I am dreaming of a part of myself that was arrested at that particular period. These dreams seem to portray deep recesses of ancestral or archetypal consciousness. I don't believe they are as historically linked to my childhood as much as they are related to a certain depth of response to a current situation. The house of memory is my grandmother's house on Front Street in Strathroy, Ontario, a yellow brick house built by my great-grandfather in 1880 when she was born, and sold after her death thirty years ago. It spans her life of eighty-two years. Room after room, it lives on unchanged in my dream life even when it is relocated and the levels of meaning shift.

My body has assumed this house as its own mirror, a genetic reflection through the maternal line. All the important shifts and stages of my waking life seem to be worked out there against the backdrop of ancestral advice which I've internalized. And what I read by day runs parallel to my night life. This musing is corroborated in Rilke: "As I find it in the memories of my childhood, it isn't a complete building; it has been broken into pieces inside me; a room here, a room there, and then a piece of a hallway that doesn't connect these two rooms, but is preserved as a fragment, by itself. In this way, it is all dispersed inside me... all this is still inside me and will never cease to be there. It is as if the image of this house had fallen into me from an infinite height and shattered upon my ground." (The Notebooks of Malte Laurids Brigge 25)

I dream of Strathroy. My grandmother's house exists for me in a kind of golden haze, the lost Atlantis of childhood, more important in my dream journal than houses I have inhabited for much longer periods of time. In that house, secret spaces foster the imagination. The instinctual self demands recognition here, in the form of odd animals that Nanny would never have allowed inside. As in this dream from December 16, 1991:

Even in my grandmother's house, there's no available space for my partner to work. But I've noticed a space above the stairs, a wide flat parquet floor which could be cleaned off for him. It's inundated with squirrels. How do they get in through the roof? Till now, they've kept to this landing. I've only seen one or two scamper up and down the banister. At the entrance to the landing, four redheaded woodpeckers hang in a row, as if they were carved, ready to peck. 
In my grandmother's house, anything can happen but the outcome is secure. It is the place of fairy tales and folklore. Its day is Sunday, its season summer. It is celebration, holidays. At home in the quotidian with my parents, illness could strike. Mother could have polio, father a massive coronary: dad had his first heart attack when I was eleven. That was the end of my safety, though I didn't grieve it then. Bruno Bettleheim states that when in the concentration camps, people dreamed of all they missed, remembered and longed for. It is only when they are released that the unconscious is prepared to begin to deal with the experience, and they dream of the camps. Now that I am safe, I dream the events I did not grieve as a child. Through the woods, through the turmoil of childhood, got to get to Nanny's house. There is safety there, and unconditional love, and Sunday dinner. No matter what happens, it is a place of happy endings. Even when Nanny died and the house was sold, it is constant. The building just changes dimension, lifting off into a dream reality.

Perhaps, such a house, despite its specificity, links with your own memories. So let me take you through its different rooms, to locate and spin their stories from bottom to top.

The cellar is dark and clammy. The door leads off the kitchen down the rickety old stairs. Nanny sends me down for a bottle of jam, a jar of pickles, and I, the practicing hero, set off unlighted, without Ariadne's practical comforting thread, on my quest. In this delicious unknown, nothing dreadful can really happen.

Downstairs, a light bulb hangs from the ceiling; a bump with my head sets it swaying. I never dream of that cellar, but each time I reach deep into my unconscious to find a poem, I seem to recreate that venture down the shaky wooden steps into the low-ceilinged, dank darkness. The treasures on the cobwebbed shelves were treats to be retrieved and eaten. Jars and jars of conserved light. Peach marmalade with maraschino cherries. Astrakan apple jelly. Strawberry jam. Pears and tomatoes. Chili sauce and pickled cucumbers.

The parlour is Victorian, hardly used and perfect. There I dutifully play the piano for my grandmother, who sits on the green love seat opposite, tapping her foot and clapping. The living room holds more treasures, games and the books and toys of my grandmother's childhood. I spend hours on my belly reading early primers, with their quaint etchings, just the right size for a child's hand. Or examining the intricate swirl 
of giant marbles, spinning the spinning wheel, playing crokinole. The circle games whirl me back in time to the 1880's. Out on the porch, rocking away the summer evenings, Nanny tells me stories of what it was like on the farm when she was a girl.

Upstairs, in the bedrooms, it is always summer. The air is lightly powdered and very warm. Breezes waft through the open window, billowing the Swiss dot curtains. White muslin is swagged to let in the light. Upstairs, there is always a girl who sprawls across one of the beds, reading Jane Austen while her grandmother naps in the endless afternoon. The window looks out into the apple tree, heavy with reddening summer apples that hang over the tin roof.

These apples are ready in July, ready to be made into marvelous jelly. The mashed apples drip overnight through solid cloth, the contraption hanging from the legs of an upside down chair. In the morning, we find the cloth stained a gruesome red, and the pan filled with juice. "Never squeeze the cloth for fear of clouded jelly," Nanny warns. With leftover dough, we flute tart shells and fill them with apple jelly.

The kitchen is the heart of the house. Grandmother and child thrive on the ritual of food, always the same food. In the hot summers when I come to stay, we eat beef steak tomatoes and fried beef steak. The meat is floured and hammered on a wooden board, then seared in a hot iron frying pan till the fat sizzles. Nanny wipes her hands on her apron and grins, dripping in sweat.

Autumn means pumpkin pies. One fall, there is a shift. As always, dessert is served, redolent. But this Sunday, the crust is cardboard. Does Nanny notice? We all chew politely in the face of declining powers of memory. Did I put that second cup of flour in or not? The family looks out the dining room window. A Rousseau jungle of aspidistra and Sansevieria plants border the glass. The yard is overgrown. Giant hollyhocks nod against the window. The flowering quince acknowledges no change.

My grandmother's place is not lost but absorbed into my bloodstream. She herself has disappeared into my recollection of her house. In sifting through my dream journals, I notice an internal patterning in which her house becomes a matrix, fluid, plastic, secure and accommodating, into which I can pour new ideas and associations, and from which poems spring.

Through Nanny's front door, I move into other times, other sites that 
would never have appeared in the strait-laced Strathroy of my grandmother's time. My dreams belie the monolithic culture of agrarian Ontario in which she was corseted. For her, the only church was the United Church, the centre of social life with its quilting bees and bake sales and comforting rituals untouched by paganism or what she would call Popery. Society was the established farm community she was raised in.

The colonial culture of my grandmother is receding, almost forgotten, as in this dream: My grandmother's house has been made over into a co-op, which I explore curiously. Upstairs, I raise the blinds in my grandmother's window. They droop back down, pink. No-one else has time to notice - too busy getting off to work in the morning. One Englishwoman apologizes: "At last, I'm retreating." Making way for a multicultural society.

Nanny would never recognize the house as I dream it, as I have assimilated it. March 28, 1991: My partner and I have just moved into my grandmother's house on Front Street. Our bedroom is where the kitchen was; our bed is on the floor. This morning we are awakened early by the drone of Gregorian chant. I know the Portuguese women upstairs are devout Catholic and would be praying in Holy Week. But the sound is muffled, as if it is coming from a truck's loud-speaker outside.

I am tossing and turning with an extra weight: two tom cats have made our bed theirs and are snuggled around my neck. Their soft white and tan fur seems clean, but since it's summer, they have to sleep outside. I don't know how they got in the screen door, but I usher them out, along with three other cats. For the winter, I'll build them a shelter along the outside wall which I can then use as a greenhouse in the spring for forcing plants.

There is a knock on the back door. I open it just a bit, because I am only wearing a long shirt as night-dress. Five or six older Portuguese or Greek men of the neighbourhood have laid a new porch and sidewalk out the backstep as a welcoming gesture. They've already poured the fresh cement, demarcated by boards. When I thank them profusely, they are pleased. So pleased that two of the more elderly turn up with a big sheet of plastic on the neighbour's roof, and jump onto ours. Did our roof need fixing? From that height, the men show off their balance, one perched precariously on a pillar like a monk in Athos.

My grandmother would not have approved. But in my dreams, her views have broadened.

July 12, 1991: My grandmother's yard has been spruced up: it is now all grass, facing directly into the little cottage at the back. Mom tells me that two 
women live there who have become her friends and Nanny's. As the women make their way out of their cottage to walk their little pet pig across the lawn to our kitchen, I make a joke about the creature. They do not approve of my humour and I soon get my comeuppance on the lawn. It turns out there's a pig here too, a long pink creature, who, when he stretches up on his trotters, can lick my cheeks. He's enamored of me and nearly bowls me over with his demonstration of affection, even pressing his penis against me. Luckily, he responds instantly to my command, "Down. Sit. Stay." I'm impressed at how clever he is. The four women are greatly amused.

Occasionally, the house is precarious, shape-shifting. From December 3, 1991: Our new property is a narrow stretch by the road, covered in red tulips. But I can hardly get out to it. For me to step out, the side of the house folds down like a cardboard box, flattening the flowers.

The Strathroy house is not just a personal memory; even its architecture has colonial brick upper stories resting on a hidden midden. The house seems to conjure imprints from the land itself, from the Huron and Neutral Indians who settled in villages in Southwestern Ontario to grow their corn.

February 27, 1991: A tall white-haired man I know lives in the house behind my grandmother's with his three daughters. Because they are poor, they have a much more intensive garden than we do, and spend much of their time in it. His corn is high because they have composted so well. Ours is dry at the stalk, though my little oregano plant at the doorway has grown into quite a bush despite my neglect. One morning he asks me to help weed with his daughters.

My reply resounds through the decrepit little barn that connects our properties and seems, to my embarrassment, to knock a few jars off the shelf. Our inspection dislodges the startled culprit-a rather ratty looking blue jay, who has been feeding in the provisions of wheat berries. We chase him toward the light of the open barn doors, hoping he has not been captive there all winter.

The dream story continues without intermission to reclaim a history of Western culture as well: I must go back into my grandmother's house, despite the languid summer's morning, and memorize Virgil. At the door, I catch a squirming sparrow. It shits and I release it. Inside, I learn the rhetoric and metaphors of literature; for example, Henry James used a mountain face to describe a skyscraper. In this house of memory, all of literature is available to me. I pore over verse forms, scanning the Latin. The elderly aunt who is my teacher recites from memory the spondees and light rhymes of German poetry which she claims are so much more spontaneous than English iambic pentameters. 
Outside the house, is the green pagan nature spirit whose realm is the yard, with its ancient and alarming vegetation. And Tara, the Tibetan deity to whom I am devoted. She represents compassion, with one foot in this world, ready to protect.

I return to the cool of the barn beside the apple tree.

There, at the long cedar table with the children, I stir bowls of fruit as a gift for the Tibetan Goddess, Green Tara. We are interrupted by several visitors, whom my son seats quickly, so as not to disturb our ceremony. Then a slender green boy I don't know skips in and out like an elf: "What an ineluctable lout I am," he declaims, when he finds us in the midst of ritual, and retreats back into the sunlight.

The separate bowls of crushed fruit-currants, grapefruit and raspberry-are set in a configuration with flowers, hollyhocks from the garden. Once the fruit is stirred, a divine young dancer appears. She seems to be the Goddess herself, Green Tara, drawn here by our offerings. Every move she makes is grace itself. She shows me how to cut a lemon to place on top. "The way you cut it will be a sign of how you live," she tells us. Carefully, I follow her example in slicing a whole circle of rind, all of a piece.

Here I am, recording and sorting through all these dreams in order to remember this other realm. Maybe a mistake; often the dreams are tantalizing distractions. But sometimes the most innocuous lead me very far back. At first I dismissed the following dream as fragments that could easily slide back into the unconscious without any intervention of memory. Even now, I don't know where they lead. I just sit with them as they evolve out of the depths.

April 1, 1991: My grandmother's back yard has become an animal path, its green stampeded into dust. My daughter rides one of the white horses on a trail. Seeing my face in the door way, she tries to veer her horse towards me. That sets the other horses galloping toward the door also. In the melee, she is moved along past me to the left, having a good time: she is not threatened by her precipitous ride. Following the horses, a pack of black, white and tan hounds, tails up for the hunt, runs like a single beast after the horses.

"Look," I remark to the family. "The door is as thin as birch bark." It is the same kind of translucent white, with black horizontal strips, as the tree. You would think that at any second the animals would barge through, but the door seems firm enough to fend them off. The creatures' bulk slides past it along the wall. Concerned, Dad inspects the door's caulking to see if it will continue to hold against the onslaught. 
Inside my grandmother's house, everyone is gathered, milling around the dining room. Nanny herself is here: her face floats beneficently, vaguely, above the dining room table by the china cabinet. The reason for our excitement is a sudden scurry on the old oak table. A tiny Santa and his six miniature reindeer have shot through the living room door to land on the table - sliding along the mass of tissue paper as if it were snow and careening a delicate passage between all the Christmas decorations to a halt just at the centre. Santa alights and stretches. I bring him a small glass of brandy out of the decanter, an offering which is as much a propitiation as a welcome. Piping up in his shrill little voice, arms akimbo, Santa promises to take me with him on his next flight. I'm ready to climb into the sleigh whenever he calls. My parents are not so sure of the whole venture, but my kids are thrilled. Wondering what to bring with me on the ride, I bustle around the kitchen, looking for winter clothing.

Something evolving here, not yet formed. The humped backs of the horses en masse give a collective sensation. These creatures all act as one, with a collective mind, like instinctual forces. They are as intensely physical as the organs of my body. The whole family is assembled at my grandmother's house, even Nanny herself. Her physical presence in a dream is rare; she is usually represented by her house.

Though she doted on her family, my grandmother is self-sufficient. She is wisdom as well as love, the voice of the elders. They represent more a band of consciousness, a band of sisters-elders who have tracked the way before me. The house of memory prepares me for a time when learning is difficult, and language is lost. As on July 2, 1991:

When I finally reach the dentist's, he is pruning a shrub by his porch. His house is very much like Aunt Laura's yellow brick one in Strathroy. "Did you know what time your appointment was?" he asks. It is almost eleven. "Could you wait?" I explain that I have another doctor to see before twelve.

On the crowded bus, the dentist introduces me to his blonde wife across the aisle. She is chanting different letters which he thinks I should learn. She splits the letter by inserting the sound of F between $T H$, the tongue between the teeth. It's a combination of difficult fricatives, but finally I get it right and practice on my own.

This line of rant presents itself like ticker tape in my brain, like the line of type on the computer typewriter. But once off the screen that line is irretrievable. Even though I hear its voice so clearly it ricochets around my brain. If I don't get it down immediately, it turns off with a sudden downward droop, and I don't know how to turn it back on. I am almost 
asleep but the computer is at my bed side. I type with my eyes closed, until I peek and see that my right hand is on the wrong keys, so I am typing gibberish. Like Aunt Laura's speech.

\section{The Stroke}

The first thing, the only thing that Great Aunt Laura could say after her stroke was: "Three..........Times."

She spoke emphatically, oracular as Sibyl, these difficult syllables. She knew.

What? That things come in sibilant

threes. Three's a crowd. I'll sing you three-oh. Threeee threeeee the rivals. Her thought a chorus of pure prayer. I stood over her while she rocked and rocked, invoking those "Three Times." She jabbed a finger south

pointing and beaming, fixing her cataract stare where the son she so doted on in her dotage lived

with his wife but did not visit. While Peter in the garden wept.

Her eye was milk of magnesia blue bottle blue. Her hair was white, shrill against pink scalp.

After a time, she learned yes, she learned no. Of all the useless words to speak, yes and no, I thought: she could have nodded, she could shake her head, but, no, she had to speak her gesture no 
matter how hard. What other words, I wonder could otherwise bracket her unconditional world.

What would spook her when the time came a third time around.

The Buddha of the Three Times abiding in the Heart Sutra.

The Three Times, where past meets future in the present. August 5, 1991: A gathering for my Tibetan teacher, Zasep Rinpoche, in the yard of my grandmother's house. Some of the women are new. One of the women asks me where I'm from. "Toronto." And how do I like the big city? I conjure up images of all the different nationalities on the Danforth. Wonderful.

We're gathering into the van and car to head up the road from Strathroy to have the vehicles checked. By the gas station, there's a Scottish tea room. Several white-haired women in white rooms bustle about the tables, wiping them off. I sit down at the far table, and a m joined by another woman who congratulates me on the find. How could I not remember this place, which is owned by my aunts? The tea and scones are very long in coming, however.

Ancestral inheritance collides with chosen cultures to form the mix I recognize as myself. On September 25, 1992, a dream: My hair has turned white all of a sudden. I am becoming my grandmother. I remember everything about her life as if it were mine. I wear my own life like a shawl around my shoulders.

With relief I wake up still with red hair, still protected by the house of memory. 